\title{
Investigation of Pre-School Childrens' Self-Concept in terms of Emotion Regulation Skill, Behavior and Emotional Status
}

\author{
Emel Arslan*
}

Necmettin Erbakan University (Turkey).

\begin{abstract}
Título: Investigación del autoconcepto de los niños en edad preescolar en términos de habilidad para regular las emociones, comportamiento y estado emocional.

Resumen: El propósito de la presente investigación es presentar las relaciones predictoras entre el autoconcepto, la regulación de las emociones, el comportamiento y el estado emocional en niños de 5 a 6 años y probar el conjunto de modelos de acuerdo con estas relaciones. La presente investigación adoptó el modelo de encuesta relacional, que es un subtipo de modelo de encuesta general. El grupo de trabajo de la investigación está conformado por 263 participantes (136 niños y 127 niñas), quienes fueron seleccionados entre el alumnado de varios centros de preescolar. Las herramientas de recopilación de datos utilizadas para la presente investigación son Purdue Self Concept Scale for Preschool (PSCS), Emotion Regulation Checklist (ERC) y Preschool Behavioral and Emotional Rating Scale (PreBERS). Se realizó un análisis de modelos de ecuaciones estructurales para presentar las relaciones predictoras entre el yo, la regulación de las emociones, el comportamiento y el estado emocional entre los estudiantes de preescolar y para investigar sus efectos. El análisis de modelado de ecuaciones estructurales se realizó con el programa de software AMOS 19. En el modelo final obtenido en la presente investigación $\left(\chi^{2}=201.711, d f=\right.$ $71, p<.001$ ), se encontraron cuatro exógenos (aceptación física, académica, social y materna) y seis endógenos de comportamiento y estado emocional, regulación emocional (dz, oh, sg, aao, regulación de las emociones y negatividad de la variabilidad). El índice de ajuste normalizado (NFI) de Bentler-Bonett, el índice de ajuste eficiente (TLI) de Tucker-Lewisco y otros índices de ajuste mostraron que el modelo presentaba un buen ajuste. De acuerdo con los hallazgos obtenidos con las relaciones predictoras, hubo una relación lineal positiva entre el yo y la conducta y el estado emocional y hubo una relación lineal positiva entre el autoconcepto y la regulación de las emociones entre los estudiantes de preescolar.
\end{abstract}

Palabras clave: Habilidades de regulación emocional. Autoconcepto. Estado emocional e hijos.

\section{Introduction}

Individuals are in interaction with their social environment as of birth. Experiences, stimulants and everything felt during interactions with the environment affect children's not only physical and mental development but also their selfconcept. Self-concept refers to the perceptions related to one's own strengths, weaknesses, skills, attitudes and values (Slavin, 2013). According to Rogers, self is the "hypotheses developed by individuals about themselves" (Cited in: Hamarta, Arslan and Yilmaz, 2014). While children develop ideas about themselves, the behaviors and attitudes of the people they care about, and how they perceive these are important. As a result of the interaction with the environment, children develop positive or negative opinions about them-

* Correspondence address [Dirección para correspondencia]:

Emel Arslan, Department of pre-school education, Ahmet Keleşoğlu Faculty of Education, Necmettin Erbakan University, Konya, 42090 (Turkey).

E-mail: emelarslan@erbakan.edu.tr

(Article received: 1-3-2019, revised: 15-10-2019, accepted: 21-2-2021)
Abstract: The purpose of the present research is presenting the predictor relations between self-concept, emotion regulation, behaviour and emotional state among 5-6 years old children and test the model set in accordance with these relationships. The present research adopted the relational survey model, which is a sub-type of general survey model. The work group of the research consists of 263 children (136 boys, and 127 girls), who were selected among students of various pre-schools schools. Data collection tools utilized for the present research are Purdue Self Concept Scale For Preschool (PSCS), Emotion Regulation Checklist (ERC) and Preschool Behavioural and Emotional Rating Scale (PreBERS). Structural equation modelling analysis was conducted to present the predictor relationships between self, emotion regulation, behaviour and emotional state among pre-school students and to investigate their effects. Structural equation modelling analysis was conducted in AMOS 19 software program. In the final model obtained in the present research $\left(X^{2}=201.711, d f=71, p\right.$ $<.001$ ), there were four exogenous (physical, academic, social and mother acceptance) and six endogenous behaviour and emotional state, emotion regulation (dz, oh, sg, aao, emotion regulation and variability negativity) data. The Bentler-Bonett normed fit index (NFI), The Tucker-Lewisco efficient fit index (TLI) and other fit indices showed that the model presented a good fit. According to the findings obtained with predictor relationships, there was a positive linear relationship between self and behaviour and emotional state and there was a positive linear relationship between self-concept and emotion regulation among pre-school students.

Keywords: Emotional regulation skills. Self-concept. Emotional status and children. selves (Kulıçaslan, 2012; Kılıçç1, 1992; Geçtan, 1990; Cevher and Buluş, 2006; Zincirkıran, 2008; Yavuzer, 1998; Hamarta, Arslan and Yilmaz, 2014; Karaca and Aral, 2017). The concept of self is a social concept the develops and changes as a result of the interaction of inborn features with the environment (Hortaçsu 1991; Kuzgun, 1979). Rogers underlines the importance of sense of self and defines sense of self as how individuals perceive themselves (Cited in: Karaca and Aral, 2017).

The most critical period of human development in terms of growth and development is early childhood (0-6 years) period (Oktay, 2004; Zincirkıran, 2008; Kılıçaslan, 2012). The foundations of self-concept, which develops as a result of interaction with family environment as of birth, are laid in the family environment during early childhood (Yüksel and Kurtuluș, 2016; Turașl1, 2014; Sarıca and Yazıc1, 2013; Metin and Bencik Kangal, 2012). The experiences obtained during this period form the values and judgement of individuals about themselves (Hortaçsu, 1991). Individuals' experiences, the feedbacks they receive and their interpretation of these during the formation and development of sense of self define 
individuals' self-respect levels (Sarıüce Körükçü, 2004). Self-respect shows us how we evaluate our talents and skills (Slavin, 2013). Individuals' opinions about who they want to be form their ideal-self. Ideal self is the sense of self that an individual wants to have (Hamarta, Arslan and Yilmaz, 2014).

Many researches have emphasized the importance of pre-school period in self-development so far (Turaşli, 2006; Zincirkıran, 2008; Sarıca, 2010; Yakupoğlu, 2011; Yıldırım Kurtuluş, 2016; Yavuzer, 1998). Additionally, the family environment the children are raised in has a very important place in the formation of their opinions about themselves (Sarica and Yazic1, 2013; Karaca and Aral, 2016; Skowron, 2005; Rosnay et al. 2006; Eroğlu, 2001). A previous research showed that there was a significant and positive relationship between mothers' child rearing behaviors and their children's sense of self (Yıldız Çiçekler and Alakoç Pirpir, 2015). The families, in which children with high self-esteem are raised, are in an attitude of mutual trust, good communication, tolerance and confidence towards their children (Kiliçarslan, 2012). The opportunities provided play an important role in children's growing up as individuals with high sense of self. Additionally, close and sensitive child-parent relation contributes to a positive sense of self (Yıldız Çiçekler and Alakoç Pirpir, 2015; Akşin Yavuz, Güven, Bayındır, et al., 2016). Parents should provide their children with an interaction environment where self-esteem can be formed (Yavuzer, 2010). Children, who have positive perceptions, ideas and feelings for themselves, develop positive behaviors (Kilıçarslan, 2012).

Research shows that peer relations also affect selfesteem. Positive relations contribute to positive development (Eryllmaz, 2009; Zimmerman, Copeland, Shope and Dlelmnn, 1996; Y1lmazel and Günay 2009). Children make social comparisons, reflect their own self-image on others and learn to get to know themselves in friendships (Yavuzer, 1998). Moreover, it was found that high self-esteem affects social relations positively (Kuzgun, 2002; Plummer, 2011). Increase in social skills also has a positive effect on self. Cerrahoğlu (2002) reported that social skills education given to $7^{\text {th }}$ grade children affected their self-concept scores. Uysal and Kaya Balkan (2015) found that according to mother reviews, social skills education affected pre-school children's social skills and senses of self.

Development of children's emotional balance also affects the sense of self significantly. Accordingly, healthy emotional development is the foundation of healthy personality and social development (Aral, Baran, Bulut, and Çimen, 1981; Kandır and Alpan, 2008). Children's establishing positive social relations with adults and their peers, regulating their emotions and expressing these in accordance with the environmental conditions are among the most important element of pre-school socio-emotional development (Çorapç1, Aksan, Yalçın, Yağmurlu, 2010). Parent attitudes also play a very important role in children's social and emotional development (Öztürk Samur, 2011; Kandır and Alpan, 2008).
According to research, pre-school period involves many important tasks in terms of development. Foundations of many behaviors are laid during these years (Dinç, 2002; Saltal1, 2013; Karaca, Gündüz and Aral, 2011). Foundations of socio-emotional behaviors and emotional development are also set in this period (Saltal1, 2013; Seven, 2007). During pre-school period, children develop skills of understanding feelings resulted from events as they develop skills of identifying emotions (Gallese, 2003). Underdeveloped emotional skills can produce negative consequences in terms of psychological health and social relations (Mecklem, 2008). Emotions help not only in regulating ourselves and our environments, but also in making meaning of life and focusing on the effects of such emotions as regret, sorrow and anxiety on the well-being of individuals (Greenberg, 2004). Emotional development is affected from other development areas and all the social, behavioral, cognitive and psychological features of individuals (Ribes, Bisquerra, Agullo et al., 2005). By helping children with exploring, expressing and sharing their emotions, we can help them understanding both themselves and others (Öztürk Samur, 2011). The skill of understanding emotions refers to realizing the underlying causes of emotions, that individuals can experience multiple feelings at once and how an emotion develops (Saltal1, 2013). Expressing feelings is a skill that is positioned in the center of emotional skills and social relations, since the correct expression of feelings can develop relationships while wrong expression can deteriorate the communication (Cited in: Saltalı 2013).

One of the main elements of emotional development is emotional regulation skill (Koçyiğit, Sezer and Yılmaz, 2015). Gross (1998) summarizes emotional regulation as the ability to affect and express the emotions we have (Cited in: Karacaoğlan, 2015). The process of regulating emotions involves being aware of the emotions, identifying and directing emotions, having the ability to adapting to the emotions and effectively using them with emotional maturity (Töremen and Çankaya, 2008). Regulating emotions refers to the efforts paid by individuals to affect the emotions they have, how they experience and express their emotions (Şarlak, 2008). Children's experiencing different affectivities, increasing or decreasing the intensity of the emotions created by a certain situation, managing the duration of the emotional intensity and transferring from one emotion to another are all related with their emotional regulation skills (Saltalı, 2013). Emotional regulation skills include being able to decrease or increase the intensity of the emotions in accordance with objectives or just staying in the same condition (Şarlak, 2008; Cicchetti, Ganiban and Barnet, 1991) Emotional skills play an important role in development of social skills, preventing behavioral problems, peer relations and academic achievement among children (Denham, 1998; Saltal1, 2013; Durmusoglu Saltalı and Deniz, 2010). Socially and emotionally strong individuals are more successful in solving social problems, self-knowledge and understanding, interpersonal relations and many other areas (Kabakçı and Korkut, 2008). 
Children with underdeveloped emotional regulation skills experience problems in socialization, academic failures and behavioral problems in school environment (Calkins \& Howse, 2004; Campbell 2002; Hyson, 2004; Walker and Golly, 1999; Novick, 2004; Duncan et al., 2007). Socially and emotionally well-adjusted children are more successful, have higher self-confidence, better human relations and communications (Öztürk Samur, 2011).

The sense of "interference" during pre-school period plays an important role in the positive development of self. The behaviors are venturous and sociable. If children are criticized too much for their behaviors and interests during this period, they lose their interference strength and develop sense of guilt. When children are discouraged or punished frequently for their interference and interests, they develop an unconfident identity and disvalue what they do. If children form such a sense of self, they can grow out to be over timid individuals, who lack sense of interference, which results in timidity and dependence during adulthood (Güngör 1993). It is believed that the sense of self developed by children affect their emotions and behaviors at an important extent. Accordingly, the purpose of the present research is presenting the predictive relations between emotional regulation skills and sense of self; and behaviors and emotional state among children and investigating the effects of these.

The purpose of the present research is presenting the predictor relations between self, emotion regulation, behavior and emotional state among pre-school students and test the model set in accordance with these relationships.

\section{Method}

\section{Research Model}

The present research adopted the relational survey model, which is a sub-type of general survey model. Relational survey model is utilized to define the relationships between two or more variables and to obtain clues related to cause and effect (Büyüköztürk, Kılıç-Çakmak, Akgün, Karadeniz and Demirel, 2008).

\section{Study Group}

The work group of the research consists of 136 boys, 127 girls, and the total of 263 5-6 years old children, who were selected through convenience sampling method among children of various pre-schools. The children to whom the scales are applied have an identified emotional disorder or learning disorder, etc. has no problems. Applications were made with the permission of the children's parents.

\section{Instruments}

Purdue Self Concept Scale For Preschool (PSCS). Purdue Self Concept Scale For Preschool (PSCS) was developed by Cicerelli (1974). The scale was translated and adapted into Turk- ish by Özcan, Eren-Gümüş, Kotil and Sarıca (2009). PSCS is a 16-items and consists of four subscales. Subscales names are physical efficiency, academic efficiency, social efficiency and mother acceptance. The internal consistency coefficients of the scale were found to be .55 for the physical efficiency, .80 for academic efficiency, .74 for social efficiency and .56 for mother acceptance. The internal consistency coefficient of the scale is .74 .

Preschool Behavioral and Emotional Rating Scale (PreBERS). The preschool behavioral and emotional rating scale was developed by Epstein ve Synhorst (2009). The scale was translated and adapted into Turkish by Öztürk-Samur, Deniz, Durmuşoğlu-Saltalı, and Ar1 (2009). The scale consists of four subscales and a total of 42 items. The internal consistency coefficients of the scale were found to be .96 for the emotional regulation dimension, .96 for school readiness, .91 for social confidence, and .62 for family involvement. High scores obtained for each subscale indicate that behavioural and emotional traits are highly rated (Öztürk-Samur et al., 2009).

Emotion Regulation Checklist. Emotion regulation checlist was devevoped by Sheilds and Cicchetti (1997). The scale was translated and adapted into Turkish by Batum and Yağmurlu (2007). The Emotion Regulation Checklist is a 24item questionnaire that yields two subscales: the Negativity/Lability scale, which represents negative affect and mood lability, and the Emotion Regulation scale. The internal consistency coefficients of the scale for Turkish version were found to be for emotion regulation subscale .73 and .75 for Negativity/Lability subscale.

\section{Procedure}

When starting to work, permission was obtained from the preschools for the application. In schools where application permission was obtained, the study was implemented after the parents were informed and the permissions were obtained. The scales used for the research were applied by the researcher. Scales were applied to 288 children. However, 25 data sets that were incomplete and incorrectly filled were excluded from the study. As a result, the scale data of 263 children were analyzed in the study.

\section{Data Analysis}

Structural equation modelling analysis was conducted to present the predictor relationships between self, emotion regulation, behaviour and emotional state among pre-school students and to investigate their effects. Structural equation modelling is a statistical approach that reveals causative relations and correlations between observed and latent variables to test a hypothetical model (Shumacker and Lomax, 2004). Structural equation modelling analysis was conducted in AMOS 19 software program. 


\section{Results}

Descriptive statistics for the scales used in the study are as in the table below.

Table 1.

Descriptive statistics.

\begin{tabular}{lcccc}
\hline & $n$ & $S D$ & Mean & Cronbach alpha \\
\hline Emotion regulation & 263 & 4.99 & 18.64 & .71 \\
Negativity/Lability & 263 & 6.08 & 11.11 & .73 \\
Emotional regulation & 263 & 7.40 & 31.37 & .88 \\
School readiness & 263 & 7.00 & 33.15 & .91 \\
Social confidence & 263 & 4.37 & 22.88 & .87 \\
Family involvement & 263 & 3.28 & 18.34 & .59 \\
Physical efficiency & 263 & 1.01 & 4.13 & .53 \\
Academic efficiency & 263 & 0.73 & 2.49 & .75 \\
Social efficiency & 263 & 0.89 & 4.48 & .71 \\
Mother acceptance & 263 & 0.58 & 2.74 & .55 \\
\hline
\end{tabular}

In the final model obtained in the present research $\left(\mathrm{X}^{2}=\right.$ 201.711, df $=71, \mathrm{p}<.001)$, there were four exogenous (physical, academic, social and mother acceptance) and six endogenous behaviour and emotional state, emotion regulation $(\mathrm{d} z, \mathrm{oh}, \mathrm{sg}$, aao, emotion regulation and variability negativity) data. Every way presented in the model was statistically significant. The Bentler-Bonett normed fit index (NFI), The Tucker-Lewisco efficient fit index (TLI) and other fit indices showed that the model presented a good fit (Table 1). All of the two-way correlations between endogenous data in the model have high values and are statistically significant. This finding is affected from the correlation values between the sub-dimensions of the scales used in the present research.

Table 2.

Statistical Values Related to the Structural Equation Model's Fit Index

\begin{tabular}{lccc}
\hline Measure & Good fit & Acceptable fit & Fit Index V Vlues of the Model \\
\hline (X $2 /$ sd) & $\leq 3$ & $\leq 4-5$ & 3.85 \\
RMSEA & $\leq 0.05$ & $0.06-0.08$ & 0.57 \\
SRMR & $\leq 0.05$ & $0.06-0.08$ & 0.07 \\
NFI & $\geq 0.95$ & $0.94-0.90$ & 0.90 \\
CFI & $\geq 0.97$ & $\geq 0.95$ & 0.95 \\
GFI & $\geq 0.90$ & $0.89-0.85$ & 0.93 \\
AGFI & $\geq 0.90$ & $0.89-0.85$ & 0.93 \\
TLI & $\geq 0.95$ & $0.94-0.90$ & 0.90
\end{tabular}

The fit values presented in Table 2 are; $\mathrm{X}^{2} / \mathrm{sd}=3.85$, RMSEA $=0.57$, SRMR $=0.050, \mathrm{NFI}=0.90, \mathrm{CFI}=0.93$, $\mathrm{GFI}=0.95, \mathrm{AGFI}=0.93$ and TLI $=0.90$. These show that the model has the desired fit values (Bollen, 1989; Browne and Cudeck, 1992; Byrne, 2010; Hu and Bentler, 1999; Kline, 2011; Tanaka and Huba, 1985). Single-factor model tested in the present research is shown in Figure 1. All ways presented in the model are significant at 0.001 level.

Table 3.

Model on predictor relations among emotional regulation, self-concept, and behavior and emotional status in pre-school children.

\begin{tabular}{|c|c|c|c|c|c|c|}
\hline Predictor Variable & Dependent Variable & Total Effect & Direct Effect & Indirect Effect & Standard Error & Critical Value \\
\hline Self-concept & Behavior and emotional status & .043 & .043 & 0 & 0.35 & $4.15^{*}$ \\
\hline Self-concept & Emotional regulation & .010 & .010 & 0 & 0.87 & $1.67 *$ \\
\hline Emotional regulation & Behavior and emotional status & 0.23 & 0.23 & 0 & 0.61 & $5.49 *$ \\
\hline
\end{tabular}

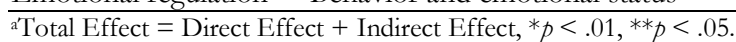

According to the model presented in Figure 1, the most important independent variable of self $(t=4.15, p<.01)$ affecting behaviour and emotional state is values. Correlation coefficient related to this factor was found as $\beta=-043$. Predictor relations between self and behavioural and emotional state among pre-school children showed that there was a positive linear relation. In other words, the increase in the sense of self among pre-school students will increase their behaviour and emotional states.

The model also shows that the most important independent variable affecting emotion regulation $(t=1.67, p<$ $.01)$ is self concept. Correlation coefficient related to this factor was found as $\beta=0.10$. The predictor relationships be- tween sense of self and emotion regulation among preschool students present a positive linear relationship. In other words, as sense of self increases among pre-school students, their emotion regulation increases accordingly.

Additionally, the tested model shows that the second most important variable affecting behavioural and emotional state $(t=-3.91, p<.01)$ is emotion regulation. Correlation coefficient related to this factor was found as $\beta=0.23$. The predictor relationships between emotion regulation and behavioural and emotional state among pre-school students present a positive linear relationship. In other words, as emotion regulation increases among pre-school students, their sense of self increases accordingly. 
Figure 1.

The path diagram of the study's model.

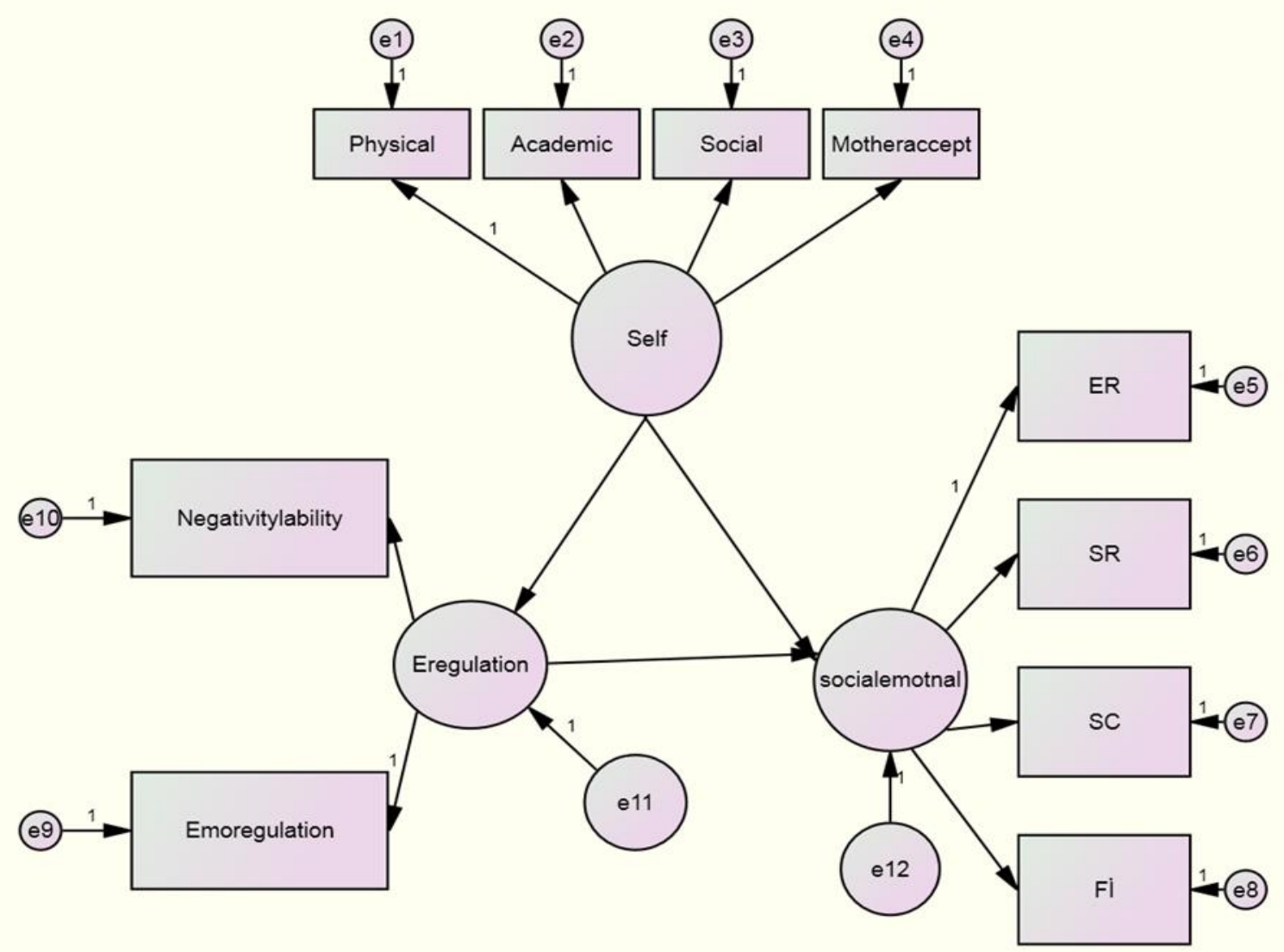

\section{Discussion}

Structural equation modelling analysis was conducted in order to present the predictor relations between self, behavioural and emotional state and emotional regulation among pre-school students and to investigate the effects of these relations. According to the obtained findings, predictor relations between self and behavioural and emotional state among pre-school students presented a positive linear relationship. This finding shows that as sense of self increases behavioural and emotional state increases accordingly among pre-school students.

Children learn to express their emotions during preschool period (Karaca and Aral, 2016). Children are expected to establish strong emotional bonds with their parents during early childhood (Koçyiğit, Sezer and Yilmaz, 2015). Reassuring, supporting and tolerant approach from parents is the most ideal way of interaction for the social and emotional development of children (Kandir and Alpan, 2008). Mothers can help the self-development of their children by playing games with them. Children with positive sense of self can overcome dilemmas, have confidence of their skills and don't suppress their feelings. They don't avoid producing new things (Karaca and Aral, 2016). Research on the selfesteem among children shows that parents play an important role especially during early ages (Sariyüce Körükçü, 2004). Providing children with experiences, which can affect their sense of self positively during pre-school period, can contribute to their behavioural and emotional development. Children with positive perceptions of themselves exhibit more confident behaviours and they are expected to be better at identifying and expressing feelings.

Emotions cover the complex interactions including the affective element of human experiences, emotions, biological, psychological and environmental factors. Research shows that emotions have important functions in interpersonal relations and that emotions show us what or who is important for us (Southam-Gerow, 2014). Development of emotions also involves the development of self and accordingly the individuals' feelings related to themselves. Therefore, development of behaviours and emotions is related with the development of self.

Another finding of the present research is that, predictor relations between sense of self and emotion regulation among pre-school students present a positive linear relation- 
ship. This suggests that as sense of self increases emotion regulation increases accordingly among pre-school students. The number of studies on emotional regulation has increased in recent years. Emotional regulation occurs in many areas and goes through some processes. Procedural/development model and developmental model are two views put for emotional regulation. Procedural/development model of emotional regulation consists of five categories suggested by Gross and Thompson (2007). These are situation selection, situation modification, attention deployment, cognitive changes-appraisals and response modulation. Developmental model of emotional regulation relates the skill of expressing emotions during early period with basic cognitive skills and involves learning strategies (Cited in: SouthamGerow, 2014).

Emotions generally occur during social interactions and are regulated during these interactions (Şarlak, 2008). Preschool period is important for both the development of self and the acquisition of skills, which are important for emotional regulation. Experiences during this period are important for children in terms of identifying and expressing their relations with their environment, sense of self and learning where and how to use their emotions. Children, who can develop a positive sense of self, can identify their emotions.

One other finding of the present research is that according to the predictor relations found between emotion regulation and behavioural and emotional state among pre-school students, there is a positive and linear relationship. As emotional regulation increases among pre-school school children, their behavioural and emotional state increases accordingly.

Pre-school period is important for the development and regulation of emotions as well. Primarily parents, secondly the environment plays an important role in the healthy development of children. Errors in parent attitudes and negative environmental conditions affect the development of children negatively. Kandir and Alpan (2008) reported that especially during pre-school period, social and affective development was very important for children in terms of developing a healthy personality and establishing a positive interaction with their environment. Seven (2007) found that family related factor affected social behaviour problems among six years old pre-school children and social behaviour problems increased in crowded families. For emotional regulation, learning to express and identify emotions and to decide what to do about emotions during early ages is very important (Southam-Gerow, 2014).

\section{References}

Akşin Yavuz, E., Güven, G., Bayındır, D., Sezer, T., \& Yılmaz, E. (2016). Annelerin çocuğunu kabul Annelerin çocuğunu kabulnbdüzeyi ile çocukların benlik algıları arasındaki ilişkinin incelenmesi [Examination of the relationship between the self concept acceptance levels of mothers and the of children]. Abant Izzet Baysal Üniversitesi Eğitim Fakültesi Dergisi, 16(3), 1065-1081.
Consequently, increase in the sense of self among preschool children affects behavioural and emotional state and emotional regulation skills positively. Additionally, development of emotional regulation skills increases behavioural and emotional state. These findings present the importance of development of sense of self among pre-school children. Positive development of sense of self requires healthy relations with everyone interacting the children, especially their parents. Providing children with positive environmental conditions is also of great importance.

\section{Conclusion and Recommendations}

According to the obtained findings, predictor relations between self and behavioural and emotional state among preschool students presented a positive linear relationship. Another finding of the present research is that, predictor relations between sense of self and emotion regulation among pre-school students present a positive linear relationship. One other finding of the present research is that according to the predictor relations found between emotion regulation and behavioural and emotional state among pre-school students, there is a positive and linear relationship.

Depending on the results of the research, the following suggestions can be presented.

- It is necessary to raise the awareness of families for positive self-development. The explanation about what parents should be careful in this topic will contribute positively to the development of children.

- Trainings for children and families should be given about the acquisition and development of emotion regulation skills.

- Families and people who deals with children should be informed about the fact those preschool years are significant years in the development of children in various ways (through education, social media, and technological tools). Thus, the awareness should be raised.

- The numbers of such studies need to be increased in order to be detected in situations that affect the child's development and are of importance in the pre-school period.

- It needs to be continued that this study should lead to further work. Also, the studies that other variables are determined should be continued.

Disclosure statement.- No potential conflict of interest was reported by the author.

Aral, N., Baran, G., Bulut, Ş., \& Cimen, S. (2000). Social Development. Child development-2. Istanbul: Ya-Pa Publishing.

Batum, P. \& Yağmurlu, B. (2007). What counts in externalizing behaviors? the contributions of emotion and behavior regulation. Current Psychology, 25(4), 272-294. 
Bollen, K. A. (1989). A new incremental fit index for general structural equation models. Sociological Methods and Research, 17(3), 303-316.

Browne, M. W., \& Cudeck, R. (1992). Alternative ways of assessing model fit. Sociological Methods \& Research, 21(2), 230-258.

Büyüköztürk, Ş., Kılıç-Çakmak, E., Akgün, Ö. E., Karadeniz, S.. \& Demirel, F. (2008). Bilimsel arastirma yöntemleri. [Scientific research methods]. Ankara: PegemA Yayıncilik.

Byrne, B. M. (2010). Structural equation modeling with AMOS (2nd ed.). New York, NY: Routledge.

Calkins, S. D., \& Howse, R. B. (2004). Individual differences in selfregulation: implications for childhood adjustment. In P. Philippot \& R. S. Feldman (Eds.), The Regulation Of Emotion (pp. 307-332). Mahwah, NJ: Lawrence Erlbaum Sociates.

Campbell, S.B. (2002). Behavior problems in preschool children: clinical and developmental issues. New York: Guilford.

Cerrahoğlu, S. (2002). Sosyal beceri eğitiminin ilkögretim ögrencilerinin öz kavram dïreylerine etkisi, [The effectiveness of social skills training at the self concept level of the primary school students]. (Unpublished master dissertation, On Dokuz Mayis University, Samsun). Retrieved from https://tez.yok.gov.tr/UlusalTezMerkezi

Cevher, F. N. \& Buluş, M. (2006). Okul öncesi eğitim kurumlarına devam eden 5-6 yaş çocuklarında akademik benlik saygısı. [5-6 years old children' academic self-esteem in pre-school institution7. Dokuz Eylül Üniversitesi Buca Ë̆itim Fakültesi Dergisi, 20, 28-39.

Cichetti, D., Ganiban, J. \& Barnett, D. (1991). Contributions from the study of high risk populations to understanding the development of emotion regulation. In J. Garber \& K. A. Dodge (Eds.), The development of emotion regulation and dysregulation (pp. 15-48). Cambridge, UK: Cambridge University Press.

Çorapçı, F., Aksan, N., Yalçın, D.A. \& Yağmurlu, B. (2010). Okul öncesi dönemde duygusal, davranışsal ve sosyal uyum taraması: sosyal yetkinlik ve davranış değerlendirme-30 ölçeği. [Emotional, Behavioral And Social Adjustment Screening At School Entry: Social Competence And Behavior Evaluatıon-30 Scale], Cocuk ve Gençlik Ruh Sağllğı Dergisi, 17 (2), 63-74.

Denham, S. A. (1998). Emotional development in young children. New York: Guilford Press.

Dinç, B. (2002). Okul öncesi eğitimin 4-5 yaş çocuğunun sosyal gelişimine etkileri konusunda ögretmen görïsleri. [teacher opinions about the effects of pre-school education on the social development of 4-5 years old children7. (Unpublished master dissertation, Anadolu University, eskisebir).

Duncan, G. J., Claessens, A., Huston, A. J., Pagani, L. S., Engel, M., Sexton,H., Dowsett, C. J. , Magnuson, K., Klebanov, P., Feinstein, L., Brooks-Gunn, J., Duckworth, K. \& Japel, K. (2007). School readiness and later achievement, Developmental psychology, 43(6), 1428-1446.

Durmuşoğlu Saltalı, N. \& Deniz, M. E. (2010). The effects of an emotional education program on the emotional skills of six-year-old children attending preschool, Educational Sciences: Theory \& Practice.10 (4), 21052140.

Akşin Yavuz, E. Güven, G., Bayındır D, Sezer, T \& Yılmaz, E. (2016). Annelerin Cocuğunu Kabul düzeyi ile çocukların benlik algıları arasındaki ilişkinin incelenmesi [Examination of the relationship between the self concept acceptance levels of mothers and the of children ]. Abant Izzet Baysal Üniversitesi Eğitim Fakültesi Dergisi, 16 (3), 1065-1081.

Cicirelli, V.G. (1974). Purdue self-concept scale for children. Purdue University.

Eroğlu, E. (2001). Ailenin çocuklarda problem çözme yeteneğinin gelismesi üzerindeki etkisi. [The effect of family on the development of problem solving abilities of children7. (Unpublished master dissertation, Sakarya University, Sakarya). Retrieved from https://tez.yok.gov.tr/UlusalTezMerkezi

Eryılmaz, A. (2009). Barışa yönelik tutumların özsaygı ve cinsiyet değişkenleriyle incelenmesi. Investigating the peace attitudes with respect to self -esteem and gender]. Balıkesir Universitesi Sosyal Bilimler Enstitüsü Dergisi. 12(21), 23-31.

Epstein, M.H. \& Synhorst, L. (2009). Preschool behavioral and emotional rating scale. Austin, TX: PRO-ED

Gallese, V. (2003). The roots of empathy: the shared manifold hypothesis dnd the neutral basis of intersubjectivity. Psychopathology, 36, 171-180.
Geçtan, E. (1990). Psikodinamik psikiyatri ve normal dışı davramışlar. [psychodynamic psychiatry and abnormal behaviors] 13. Basım, Istanbul: Remzi Kitapevi.

Greenberg, L. (2004). Emotion-focused therapy, Clinical Psychology and Psychotherapy, 11, 3-16.

Gross, J. J., \& Thompson, R. A. (2007). Emotion Regulation: Conceptual Foundations. In J. J. Gross (Ed.), Handbook of emotion regulation (pp. 3 24). New York, NY, US: Guilford Press.

Güngör, A. (1993). Çocukta benliğin gelişimi. 9. Ya-Pa okul öncesi eğitimi ve yaygınlaştırılması semineri [Çocukta benliğin gelişimi. 9. Ya-Pa okul öncesi eğitimi ve yaygınlaştırılması semineri]. YA-PA Yayınları, Ankara

Hamarta, E., Arslan, C. \&Yilmaz, H. (2014). Eğitim psikolojisi, Educational psychology] Cizgi kitabevi.

Hortaçsu, N. (1991). Insan ilişkileri. [Interpersonal relationship]. Ankara: İmge Kitapevi.

Hu, L. T., \& Bentler, P. M. (1999). Cutoff criteria for fit indexes in covariance structure analysis: Conventional criteria versus new alternatives. Structural Equation Modeling: A Multi Disciplinary Journal, 6(1), 1-55.

Hyson, M. (2004). The emotional development of young children: building an emotioncentered curriculum. 2. Baskr, New York: Teachers College Press.

Kabakç1, Ö. F. \& Korkut Owen, F. (2008). The study of students' socialemotional learning skills in terms of some variables at 6-8 grade level. Education and Science, 33(148), 77-86.

Kandır, A. \& Alpan, Y. (2008). Sosyal duygusal değerlendirme aracının (1tsea) farklı sosyo-ekonomik düzeylerde uygulanması, [application of the infant-toddler social \& emotional assessment tool (1tsea) at various socio-economical levels] Türk Ĕgitim Bilimleri Dergisi, 6(1), 41-61.

Karaca, N, Aral, N . (2017). Yaratıcı Rahatlama Çalışmalarının Anaokuluna Devam Eden Cocukların Benlik Kavramı ve Motor Yaratıcılığına Etkisinin İncelenmesi. Kuramsal Eğitimbilim Dergisi, 10 (1), 146-169.

Karaca, N.H., Gündüz, A. \& Aral, N. (2011). Okul öncesi dönem çocuklarının sosyal davranışının incelenmesi, [1nvestigation of social behavior in preschool children] Kuramsal Ë̆itim Bilim, 4(2), 65-76.

Karacaoğlan B. (2015). Bilgece farkemdallk, duygu düzenleme becerisi ve is tatmini arasindaki ilişkinin incelenmesi [an analysis of the relationship between mindfulness, emotion regulation skills and job satisfaction] (Unpublished master dissertation, Turkish Military Academy, Ankara).

Kilıçaslan, Y. (2012). Okul öncesine devam eden 5-6 yaş gurubu ögrrencilerin benlik kavramlarmin annelerinin yașam doyumlar bağlaminda incelenmesi. [Analysing the self - concept of the preschool children aged $5-6$ in the context of their mothers' life satisfaction] (Unpublished master dissertation, Istanbul Arel University, Istanbul). Retrieved from https://tez.yok.gov.tr/UlusalTezMerkezi/

Kılıççı, Y. (1992). Okeulda Ruh Sağlı̆gr, [Mental Health at School]. Ankara: Anı Yayincilik.

Kline, R. B. (2011). Principles and practice of structural equation modeling. New York, NY: The Guilford Press.

Koçyiğit, S., Sezer, T. \&Yılmaz, E. (2015). 60-72 aylık çocukların sosyal yetkinlik ve duygu düzenleme becerileri ile oyun becerileri arasındaki iliskinin incelenmesi. [The investigating of the relationship among social competence, emotion regulation skills and play skills of 60-72 months old children] Hasan Ali Yücel Ë̆itim Fakültesi Dergisi, 12-1(23), 209-218.

Kuzgun, Y. (2002). Illkögrretimde rehberlik. [Guidance in primary education]. Ankara: Nobel Yayın Dağıtım.

Kuzgun, Y. (1979). Ben kavramı ve meslek seçimi. [Self concept and career choice]. Psikoloji Dergisi, 2(4), 12-18.

Mecklem, G. L. (2008). Practitioner's guide to emotion regulation in school-aged children's. New York, USA: Springer.

Metin, N. \& Bencik Kangal, S. (2012). An examination of the self concept of 12 to 14 year-old gifted children enrolled in science and art centers. Education and Science, 37(163), 3-16.

Novick, R. (2004). Early years are learning years. Washington: National Association for the Education of Young Children,

Oktay, A. (2004). Yaşamm sibirli yullart: okul öncesi dönem. [magic years of life: pre-school period] Epsilon Yayınları. 5. Bask1. İstanbul.

Özcan, Z. Ç., Eren Gümüş, A.\& Kotil, Ç. Sarıca, Ö. (2009). Purdue okul öncesi çocukları için benlik kavramı ölçeği'nin yap1 geçerliği. [the construct validity of purdue self-concept scale for preschool children] Eğitim Bilimler ve Uygulama Dergisi, 8(16), 2-22. 
Öztürk Samur, A. (2011). Değerler eğitimi programmm 6 yaş çocuklarmin sosyal ve duygusal gelisimlerine etkisi. [effects of values program on social emotional development of six year old children education] (Unpublished doctoral dissertation, Selcuk University, Istanbul). Retrieved from https://tez.yok.gov.tr/UlusalTezMerkezi/

Öztürk Samur, A., Deniz, M.E., Durmuşoğlu Saltalı, N. \& Arı, R. (2009). Alt yas cocuklar için davranıssal ve duygusal dereceleme ölçeği: gecerlik ve güvenirlik çalsmast. [Behavioral and emotional scale for six - year old children: validity and reliability study]. Uluslar Arası Katılımlı II. Çocuk Gelişimi Ve Eğitimi Kongresi, Sağlık, Gelişim ve Eğitimde Çocuk. Hacettepe Üniversitesi. Ankara.

Plummer, M.D. (2011). Benlik saygısı çocuklarda nasıl geliştirilir. [Helping children to build self-esteem]. İstanbul: Sistem Yayincllik.

Ribes, R., Bisquerra, R., Agullo, M., J., Filella, G. \& Soldevilla, A. (2005). An emotional curriculum proposal for early childhood education (3 to 6 years). Cultura y Educación, 17(1), 5-17.

Rosnay, M., Cooper, P.J., Tsigaras, N., Ve Murray, L. (2006). Transmission of social anxiety from mother to infant: an experimental study using a social referencing paradigm. Behaviour Research and Therapy, 4, 11651175 .

Saltalı, N.D. (2013). Okul öncesi dönemde duygusal becerilerin geliștirilmesi (enhancing emotional skills in preschool year). Yalova Sosyal Bilimler Dergisi, 6, 107-119.

Sarıca, E., Yazıc1, E. (2013). Ebeveynlerin sosyal sorun çözme becerileriyle çocukların benlik algısı arasındaki ilişki. [The relatıonship between parents social problem solving skills and children's self-concept]. Uluslararası Hakemli Aile Cocuk. ve Eğitim Dergisi,1(1), 91-103.

Sarıca, Ö. (2010). Okul öncesi eğitim kurumlarna devam eden 5 ve 6 yas grubu cocuklarmm benlik kavramlarmin cesitli sosyo-demografik değiskenlere göre incelenmesi. [An examination of 5 and 6 year-old children's self concepts according to various socio-demographic variables] (Unpublished master dissertation, Maltepe University, Istanbul). Retrieved from https://tez.yok.gov.tr/UlusalTezMerkezi

Sarıyüce Körükçü, Ö. (2004). Altı yaș grubundaki çocuklarn özsaygı düzeyleri ile anne empatik becerilerinin incelenmesi. [A study on the level of self-esteem in six-year age group childeren with the empathetic skills of their mothers ] (Unpublished doctoral dissertation, Ankara University, Ankara). Retrieved from https://tez.yok.gov.tr/UlusalTezMerkezi/

Schumacker, R. E. \& Lomax, R. G. (2004). A Beginners's Guide To Structural Equaiton Modeling. London: Lawrence Erlbaum Associates.

Seven, S. (2007). Ailesel Faktörlerin Altı Yaş Cocuklarmm Sosyal Davranıs Problemlerine Etkisi. Kuram Ve Uygulamada Eğitim Yönetimi, Sayn 51, Ss: $477-$ 499. (Educational Administration: Theory And Practice, Issue 51, 477-499).

Shields A., Cicchetti, D. (1997). Emotion Regulation Among Schoolage Children: The Development and validation Of A New Criterion Qsort Scale. Devevelopmental Psychology, 33, 906-916.

Skowron, E. A. (2005). Parent differentiation of self and child competence in low income urban families. Journal of Counseling Psychology, 52(3), 337.

Slavin R. E. (2013), Educational Psychology Theory and Practice. (Eğitim Psikolojisi Kuram ve Uygulama) Çev.Ed. Prof.Dr. Galip Yüksel. Nobel Yayınları. 10. Basımdan Çeviri.

Southam-Gerow, M. A. (2014). Emotional Regulation In Children And Adolescents (Çev. Klinik Psikolog Murat Artıran). Nobel Yayınları.

Șarlak, K. (2008). Duygusal Yașantılarda ve Duygusal Düzenlemede Gözlenen Bireysel Farkluhkelarn Cok Boyutlu Olarak. Değerlendirilmesi. Yayımlanmamış Yüksek Lisans Tezi, Muğla Üniversitesi, Sosyal Bilimler Enstitüsü. Muğla.

Tanaka, J. S., \& Huba, G. J. (1985). A fit index for covariance structure models under arbitrary GLS estimation. British Journal of Mathematical and Statistical Psychology, 38(2), 197-201.

Töremen, F. Ve Çankaya, İ. (2008). Yönetimde Etkili Bir Yaklașım: Duygu Yönetimi, Kuramsal Eğitim Bilim, 1 (1), 33-47.
Turaşlı, N. (2006). 6 Yaş Grubu Cocuklarda Benlik. Algısın Desteklemeye Yönelik Sosyal Durgusal Harrllk. Programmon Etkililiğinin Incelenmesi [nvestigation of the Effectiveness of the Social Emotional Preparation Program to Support Self-Perception in 6 Year-Old Children]. Yayımlanmamıs Doktora Tezi. Marmara Üniversitesi/Eğitim Bilimleri Enstitüsü, İstanbul.

Turaşlı, N. K. (2014). Validity And Reliability Of The Demoulin SelfConcept Developmental Scale For Turkish Preschoolers. Eurasian Journal Of Education Research, 55, 55-72.

Uysal A., Kaya Balkan İ. (2015). Sosyal Beceri Eğitimi Alan Ve Almayan Okul Öncesi Çocukların, Sosyal Beceri Ve Benlik Kavramı Düzeyleri Açısından Karşılaştırılması. Psikeoloji Calışmalar Dergisi, 35-1. 27-56.

Walker, H.M. \& Golly, A.M. (1999). Developing Behavioral Alternative For Antisocial Children At The Point Of School Entry. The Clearing House, 73(2), 104-106.

Yakupoğlu, Y. (2011). Erken Cocukluk Döneminde Yer Alan, Okulöncesi Eğitim Kurumuna Devam Eden Cocuklarn Benlik. Kavrame Algisiyla Babalarmm Bağlanma Stillerinin (Güvenli - Korkulu - Kanutsız - Saplantıli) Arasındaki Iliskinin Incelenmesi [Investigation of the Relationship between SelfConcept Perception and Fathers' Attachment Styles (Secure - Fearful Indifferent - Obsessive) of Early Childhood Children Attending Preschool Education Institutions]. Maltepe Üniversitesi Sosyal Bilimler Enstitüsü. Yayımlanmamış Yüksek Lisans Tezi, İstanbul.

Yavuzer, H. (1998). Cocuğunuұun Illk Altı Yil [Your Child's First Six Years]. İkinci Basım.

Yavuzer, H. (2010). Yaygm Anne Baba Tutumlar. Cocuk Ve Ergen Eğitiminde Anne Baba Tutumlar, Aile Eğitimi-5 [Common Parental Attitudes. Parental Attitudes in Child and Adolescent Education, Family Education5]. Timas Yayınları, İstanbul.

Yıldırım Kurtuluş, H. (2016). Okul öncesi kuruma devam eden 4-5 yas grubu ögrencilerin benlike kavramı ve bağlanma stillerinin anne davranıșlar açısından incelenmesi. Investigation of the self-concep and the attachment styles of 4-5-year-old students in preschool institutions from the perspective of their mother behaviours] (Unpublished master dissertation, Marmara University, Istanbul). Retrieved https://tez.yok.gov.tr/UlusalTezMerkezi/

Yıldız Çiçekler, C., Alakoç Pirpir D. (2015). 48-72 Aylar Arasında Çocuğu Bulunan Annelerin Cocuk Yetiștirme Davranışları İle Cocuklarının Benlik Kavramlarının İncelenmesi [Investigation of Child-rearing Behaviors of Mothers with Children Between 48-72 Months and Their Children's Self-Concepts]. Hacettepe Üniversity Faculty Of Health Sciences Journal. 1(2), 491-500.

Yllmazel, G. \& Günav, O. (2012). Corum İli Kargı İlcesinde Öğrenim Gören 12 17 Yas Arasindaki Ögrencilerde Öæsayg Ve Depresyon [Self-Esteem and Depression in Students aged 12-17 in Karg1 District of Corum]. Ercives Üniversitesi. Sağlık Bilimleri Enstitüsü. Halk Sağlığı Anabilim Dalı. Kayseri.

Yüksel, M. Y. \& Kurtulus, H. Y. (2016). Investigation of The Self-Concept And The Attachment Styles Of 4-5-Year-Old Students From the Perspective of Their Mother Behaviours. Journal of Research in Education and Teaching. 5 (2). 182-195.

Zimmerman, A.M., Copeland, A.L., Shope, T.J., Delman, E.T. (1996). A Longitudinal Study Of Self-Esteem: İmplications For Adolescent Development. Journal of Youth and Adolescence, 26(2).

Zincirkıran, Z. (2008). Okul Öncesi Eğitim Kurumlarna Devam Eden \& Yass Grubu Cocuklarmm Benlik. Kavramlarnm Bazı Değiskenlere Göre Incelenmesi Investigation of Self-Concepts of Preschool Educational \& Age Group Children According to Some Variables], Maltepe Üniversitesi Sosyal Bilimler Enstitüsü, Yayımlanmamıș Yüksek Lisans Tezi, İstanbul. 